\title{
BIOCONCENTRATION OF HEAVY METAL CADMIUM (CD) IN GREEN MUSSLE (Perna Viridis Linn, 1758) CULTIVATED IN PASARAN ISLAND WATERS, LAMPUNG, INDONESIA
}

\author{
Henni Wijayanti Maharani ${ }^{1}$. Nurulita $^{2}$. Herman Yulianto ${ }^{1}$. \\ Eko Efendi ${ }^{3}$. Putu Cinthia Delis ${ }^{1}$
}

Ringkasan Pasaran Island waters is the location of green mussel cultivation (Perna viridis), where the waters has the potential to experience heavy metal pollution including Cadmium $(\mathrm{Cd})$. Green mussels are filter feeders and have a slow movement, thus they have the potential to experience heavy metal bioconcentration on their bodies. The aim of this study was to determine the bioconcentration of heavy metal cadmium $(C d)$ in green mussels (Perna viridis) which were cultivated in the waters of Pasaran Island. Samples were collected in February 2018 in green mussel cultivating cages of Pasaran Island water with 3 and $6 \mathrm{~cm}$ mussel size. Sampling was taken at three stations with three replications each. The $C d$ content was analyzed using AAS method. The results showed that the water content of $\mathrm{Cd}$ at the observation location ranged from 0.022 to $0.024 \mathrm{mg} / \mathrm{l}$. The content of $C d$ of mussel meat is 0.030 to $0.033 \mathrm{mg} / \mathrm{kg}$, the value is below the

\footnotetext{
$\left.{ }^{1}\right)$ Aquatic Resources Study Program of Fisheries and Marine Science Departmen, FP UNILA ${ }^{2}$ )Aquaculture Study Program of Fisheries and Marine Science Deparment, FP UNILA ${ }^{3}$ )Marine Science Study Program of Fisheries and Marine Science Deparment, FP UNILA

E-mail: henny.wijayanti@fp.unila.ac.id
}

threshold based on Indonesian National Standard (SNI). The BFC value of $3 \mathrm{~cm}$ mussel is $1.33 \mathrm{mg} / \mathrm{kg}$, while the 6 $\mathrm{cm}$ mussel is $1.47 \mathrm{mg} / \mathrm{kg}$ which indicates that the green mussels on Pasaran Island are accumulatively low on $\mathrm{Cd}$.

Keywords Cadmium (Cd), green mussel, bioconcentration, Pasaran Island

Received : 05 Nopember 2018

Accepted : 12 Januari 2019

\section{PENDAHULUAN}

Pasaran Island is located in the coastal area of Bandar Lampung City, Indonesia. The waters of Pasaran Island have the potential to experience heavy metal pollution including heavy metal Cadmium (Cd). According to Wiryawan et al. (1999) the coastline of Bandar Lampung City is one of the locations that has experienced a lot of coastal land conversion into industrial areas including the coal industry, power plants, tourism, commercial ports and settlements. Waste from these industrial activities can cause pollutant increase in Pasaran Island water. In addition, 
ship traffic activities and overcrowding can also pollute coastal waters.

Cadmium is a non-essential metal for organisms (Martin and Pognonec, 2010), but is an important material in industrial activities. Naturally, $\mathrm{Cd}$ is present in nature and may cause pollution in water, air and soil. Cd can accumulate strongly in plant and animal tissues and enter the human body through the food chain (Isani et al., 2009). Industrial activities include coal mining activities, which affect the occurrence of water pollution caused by heavy metal Cd. According to Rukmana et al. (2013), liquid waste generated from the coal washing process contains dangerous heavy metals, including cadmium derived from soil and rock which is carried away during the coal exploitation process.

Based on the data reports of Lampung Province Environmental Status regarding seawater quality in the coastal areas of Bandar Lampung City, Panjang container port traffic area has $\mathrm{Cd}$ content of $0.014 \mathrm{mg} / \mathrm{l}$. The content of $\mathrm{Cd}$ in the estuary area of Pasaran Island conducted by Sembel (2011) obtained a value ranging from $0.013-0.018 \mathrm{mg} / \mathrm{L}$. This value has increased compared to previous research conducted by Yudha (2007) who only obtained a value of $0.001 \mathrm{mg} / \mathrm{l}$. Based on the Decree of Minister of Environment of Republic of Indonesia, the quality standard for seawater $\mathrm{Cd}$ content for marine biota is $0.001 \mathrm{mg} / \mathrm{l}$, therefore the water has exceeded the quality standard or in a polluted state.

The waters of Pasaran Island are currently used as a location for cultivating green mussels (Perna viridis). Green mussels are organisms that are easy to cultivate. Life requirements for green mussels are not as complicated as pearl shells that require contamination-free water quality (Yulianto et al., 2016).Mussels have the potential to accumulate heavy metal content in waters (Dumalagan et al., 2010). It can be due to green mussels are filter feeders and have a slow movement (Kamaruzzaman et al., 2011). Cadmium (Cd) is one of the heavy metals that is harmful to sedentary organism type(Biagioli et al., 2008). The nature of cadmium tends to sediment and it is difficult to degrade by organism, thus if it is absorbed by organismbody, its concentration wi11 increase with time. According to Beesley et al. (2000), mussels are the most likely accumulating heavy metals compared to other aquatic biota.

Cadmium entering human body through the food chain has potency to cause various diseases for humans (Whyte et al., 2009). According to Yestyani (2010), $\mathrm{Cd}$ can cause miscarriages in pregnant women, chest tightness, dry esophagus, decreased ability to smell, decreased body weight, teeth aching and golden yellow colored. Other health impacts according toLampe et al. (2008) may leads to disease in the lung organs. In addition, $\mathrm{Cd}$ consumption can cause bone damage (Schutte et al., 2008), as well as increasing potencyof cancer and causing death (Menke et al., 2008). Based on these conditions, it is necessary to have information regarding cadmium content $(\mathrm{Cd})$ in the location of green mussel cultivation in the waters of Pasaran Island, as well as the $\mathrm{Cd}$ content in green mussel meat and their feasibility for consumption.

This study aims to determine the bioconcentration of heavy metal cadmium $(\mathrm{Cd})$ in green mussels (Perna viri- 


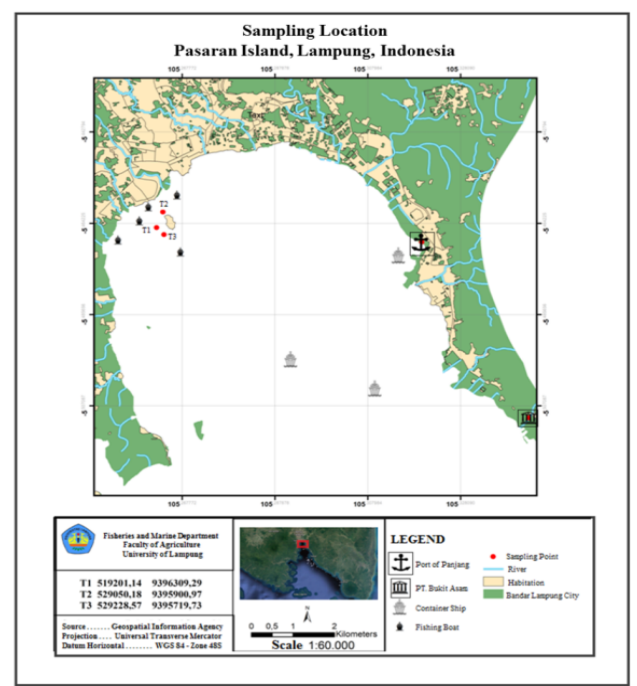

Gambar 1 Map of the sampling location, Pasaran Island

dis L.) cultivated in the waters of $\mathrm{Pa}-$ saran Island. The benefit of this study is providing information about the $\mathrm{Cd}$ content in green mussel (Perna viridis) cultivation location in the waters of $\mathrm{Pa}-$ saran Island and its accumulation impact as well asits feasibility to be consumed by the community.

\section{MATERI DAN METODE}

This research was carried out in February 2018. Sampling was conducted in green mussel cultivating cages in $\mathrm{Pa}-$ saran Island waters. Analysis of heavy metal content of Cadmium (Cd) was done at Analysis Laboratory of Lampung State Polytechnic.

The research method used was purposive sampling technique. The tools used were GPS, AAS tools, surgical instruments, scales, plastic zips, film bottles, ovens, thermometers, $\mathrm{pH}$ paper, DO kits and refractometers. The ingredients used were sea water and green mussel meat. The collection of mussels and water was carried out in 3 cage locations (Figure 1) which were determined based on the characteristics of each location. T1 location is a central location for green mussel cultivation, T2 location is a cultivation location closes to the mainland and residential areas, and T3 location is a cultivation location located near the location of fishing vesselsas well as and container and industrial vessels traffic area. Mussels sampling was carried out in 3 replications based on the cage (front, middle and back). The samples of green mussels used consisted of two groups, namely 3 and $6 \mathrm{~cm}$ mussels size.

Water quality parameters such as temperature, $\mathrm{pH}$, dissolved oxygen (DO), and salinity were measured directly at each research location. Total of $25 \mathrm{ml}$ water samples for analysis of cadmium (Cd) were taken at each location of mussels sampling using bottle of sample for analysis at laboratory. The samples of green mussels used were $30 \%$ of the total population per cagesusing random sampling methodat 30 ropes. Green mussels were grouped according to their size, which were 3 and $6 \mathrm{~cm}$. Then, each group of mussels was separated from its shell. The meat that had been separated was chopped until homogeneous and taken 100 grams as sample to be analyzed in the laboratory.

Analysis of $\mathrm{Cd}$ content in water was carried out on water sample that had been taken. Total of $25 \mathrm{ml}$ of water sample was put into tube digestions and 5 drops of $\mathrm{HNO}_{3}$ were added. The samples were heated in digestions blocks with a temperature of $100{ }^{\circ} \mathrm{C}$ for an hour, then the samples were measured with Atomic Absorption Spectropho- 
tometry (AAS) and the adsorbed values were recorded. Analysis of Cd content in mussels was conducted by using 100 grams of mussels meat that had been chopped, then being dried in oven. After the drying process, $0,5 \mathrm{~g}$ of mussels meat samples were put into tube digestions, then added $5 \mathrm{ml}$ of $\mathrm{HNO}_{3}$ and $0,5 \mathrm{ml}$ of $\mathrm{HClO}_{4}$, left for one night. The next day, the sample was heated in digestions blocks with a temperature of $100{ }^{\circ} \mathrm{C}$ for an hour, then the temperature was increased to $150{ }^{\circ} \mathrm{C}$. After the yellow steam ran out, the temperature was increased to $200{ }^{\circ} \mathrm{C}$. Destruction was complete after white smoke appeared and the remaining extract was $\pm 0.5 \mathrm{ml}$. Tube digestions were removed and left to cool, then extract was diluted using $49,5 \mathrm{ml}$ of distilled water, thus the final sample volume was $50 \mathrm{ml}$. Followed by, stirring using stirrer for 5 minutes until homogeneous. Samples of homogeneous green mussels extractwas injected into AAS tool to determine the value of heavy metal cadmium $(\mathrm{Cd})$.

Bioconcentration factor $(\mathrm{BCF})$ was calculated to determine the ability of green mussels to accumulate heavy metal $\mathrm{Cd}$ from the waters. BFC values can be obtained using the formula: (Vassiliki \& Konstantina, 1984 in Falusi \& Olanipekun, 2007).

$B C F_{o-w}=\frac{[C]_{\text {org }}}{[C]_{\text {water }}}$

Description : $\mathrm{BCF}(\mathrm{o}-\mathrm{w})=$ Bioconcentration factor (organism with water) $\mathrm{C}$ org $=$ Concentration of heavy metals in organisms $\mathrm{C}$ water $=$ concentration of heavy metals in water.

The datas had been collected were water quality data, water $\mathrm{Cd}$ concentra- tion data, data on $\mathrm{Cd}$ content on the mussels body, and data on bioconcentration of Cd metal on the mussels then compared to the established quality standards. Data of Cd metal content based on the size of green mussels $(3 \mathrm{~cm}$ and $6 \mathrm{~cm}$ ) were compared and analyzed using the t-Test with a significant level of $95 \%$. Data of Cd metal content based on cage location and shell size were analyzed using Factorial Completely Randomized Design (ANOVA) with treatment in the form of cages and groups in the form of shell size.

\section{HASIL DAN PEMBAHASAN}

Environmental conditions are important factors that influence mussels growth (Pattikawa and Ferdinandus, 2009). Water quality values include temperature, $\mathrm{pH}$, and salinity in each research sites showing optimum conditions for the cultivation of green mussels, while DO values of 5 and $4 \mathrm{mg} / \mathrm{l}$ show DO content of the waters are below the optimum value for green mussel cultivation (Table 1). Dissolved oxygen concentration in Pasaran Island is quite low compared to the results of the study according toYulianto et al. (2017) in Lampung Bay which is $5.63 \pm 0.42 \mathrm{mg} / \mathrm{l}$. According to Nurdin (2000), optimum DO for green mussels cultivation is 8 $\mathrm{mg} / \mathrm{l}$, and according to Minister of Environment's Decree regarding seawater quality standards for marine biota is $5 \mathrm{mg} / \mathrm{l}$, therefore the DO content in the research sitescan be concluded as below the DO quality standard for marine biota.

The low DO can be caused by various factors, including the increase in 
Tabel 1 Water quality in each research site/observation location

\begin{tabular}{|c|c|c|c|c|}
\hline \multirow{2}{*}{ Parameter } & \multicolumn{3}{|c|}{ Locations } & \multirow{2}{*}{ Optimum condition for green mussels } \\
\hline & $\mathrm{T} 1$ & $\mathrm{~T} 2$ & $\mathrm{~T} 3$ & \\
\hline Temperature $(0 \mathrm{C})$ & 30.8 & 30.9 & 31 & $26-32 *$ \\
\hline $\mathrm{pH}$ & 8 & 8 & 8 & $7-9 * *$ \\
\hline $\mathrm{DO}(\mathrm{mg} / \mathrm{L})$ & 5 & 4 & 4 & $8^{* * *}$ \\
\hline Salinity $(0 / 00)$ & 30 & 30 & 30 & $24-30^{* * * * * *}$ \\
\hline
\end{tabular}

organic waste in the waters. This causes oxygen in the waters to be utilized by bacteria to decompose organic substances into inorganic substances (Simanjuntak, 2012). In addition, the type of substrate can also affect the concentration of dissolved oxygen. The waters of Pasaran Island have sandy mud substrate types that are suitable to be used as location of green mussel cultivation, but the muddy substrate will cause oxygendiffusion from the air into the sediment, resulting in lower oxygen concentration (Khaisar, 2006). Less optimum of DO consentration in the location of green mussel cultivation leads to less optimal cultivation result.

Based on the analysis results (Table 2) the concentration of $\mathrm{Cd}$ in water at the observation location/research site was $0.022 \mathrm{mg} / \mathrm{l}$ at $\mathrm{T} 1$ and T2 as well as 0.024 $\mathrm{mg} / \mathrm{lat} \mathrm{T} 3$. Cd content in seawater has exceeded the threshold or quality standards according to Minister of Environment's Decree No. 51 of 2004 concerning seawater quality standards for marine biota. This shows that the waters of Pasaran Island have experienced water pollution of heavy metal $\mathrm{Cd}$, and are unsuitable to be used as aquaculture areas.

Cadmium (Cd) content in the three locations of green mussel cultivation has considerably high amount of concentration. According to Mohiuddin et al.
Tabel 2 Cadmium $(\mathrm{Cd})$ content in the water of the research site

\begin{tabular}{ccc}
\hline \multirow{2}{*}{ Location } & Cd heavy metal content & Quality standard \\
\cline { 2 - 3 } & $(\mathrm{mg} / \mathrm{l})$ & $(\mathrm{mg} / \mathrm{l})^{*}$ \\
\hline T1 & 0.022 & \\
T2 & 0.022 & 0.001 \\
T3 & 0.024 & \\
\hline
\end{tabular}

* According to [KEPMENLH RI] Decree of vironment No. 51 of 2004 concerning sea water quality standards for marine biota

(2011), heavy metals are the most common pollutants found in waters. Cadmium $(\mathrm{Cd})$ in the waters can come from natural content in the nature and human activities. Another factor that influences the high cadmium content in the research site is the cultivation location is located around the estuary area and is influenced by tidal dynamics. Gandri et al. (2017) stated that, the high content of heavy metals in estuary areas was caused by the region was a trap zone for all pollution components through tidal dynamics events. The $\mathrm{Cd}$ existence in the bay area not only comes from the land, but can also come from various areas that are carried by the current and sediment in the bay area which is the research sites. The metal will be carried by the current during high tide from the sea to the land, then when it is entering the bay the current velocity will be slightly decreased, therefore Cd metal accumulates in the area (Panjaitan et al., 2014).

Measurements of $\mathrm{Cd}$ content on two mussels sizes showed that the size of $6 \mathrm{~cm}$ had Cd content of $0.033 \mathrm{mg} / \mathrm{kg}$, while the $3 \mathrm{~cm}$ musselswas $0.030 \mathrm{mg} / \mathrm{kg}$ (Table 3). Based on the results of t-test, the $\mathrm{Cd}$ content in mussels of 3 and 6 $\mathrm{cm}$ was not significantly different $(\mathrm{p}>$ 0.05 ), it showed that the difference in mussels size did not significantly affect cadmium content in the body. 
Tabel 3 Cadmium (Cd) content based on the size of green mussels (Perna viridis)

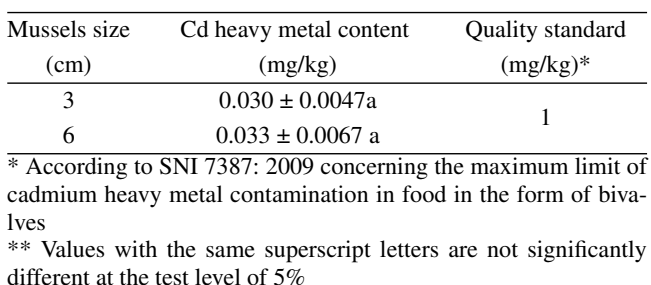

The Cd content in green musselssize 3 and $6 \mathrm{~cm}$ almost have the same value. This is presumably because the size of the green mussels used is not much different, the size of $3 \mathrm{~cm}$ is $3-4 \mathrm{mon}-$ ths old mussels, while $6 \mathrm{~cm}$ mussels are 6-7 months old where the size is ready for harvest. Body size indicates that the age of mussels taken is not much different, thus the exposure length of metal cadmium in these waters is not much different. Therefore, the impact of Cd metal accumulation on green mussel body is not too different or relatively the same.

The cadmium content value of green mussels is $0.030-0.033 \mathrm{mg} / \mathrm{kg}$ which is still below the threshold based on SNI, therefore it is still suitable for consumption. However, the amount of consumption needs to be watched because $\mathrm{Cd}$ has high toxic effect even at low concentrations (Almeida et al., 2009). Cd is accumulative and has a long halflife in the body of living organisms so that if consumed continuously can cause adverse effects on human health. Provisional Tolerable Weekly Intake (PTWI) or limit tolerance value for consumption of cadmium heavy metals per week according to FAO / WHO (2004) is $7 \mu \mathrm{g} / \mathrm{kg}$ body weight per week. Based on PTWI value calculation results, cadmium is $0.007 \mathrm{mg} / \mathrm{kg}$ assuming that individuals who consume $50 \mathrm{~kg}$ are obtained MWI (Maximum Weekly Inta-
Tabel 4 Cadmium $(\mathrm{Cd})$ content in green mussels based on the size and cages location

\begin{tabular}{cccc}
\hline \multirow{2}{*}{ Mussels size (cm) } & \multicolumn{3}{c}{$\begin{array}{c}\text { Cd heavy metal content } \\
(\mathrm{mg} / \mathrm{kg})\end{array}$} \\
\cline { 2 - 4 } & Location T1 & Location T2 & Location T3 \\
\hline 3 & $0.0333^{a}$ & $0.0300^{a}$ & $0.0267^{a}$ \\
6 & $0.0300^{a}$ & $0.0333^{a}$ & $0.0367^{a}$ \\
Mean & 0.0316 & 0.0316 & 0.0317 \\
* Values with the same superscript letters are not significantly di- \\
fferent at the test level of 5\%
\end{tabular}

fferent at the test level of $5 \%$

ke) value of $0.35 \mathrm{mg}$. This value indicates that the maximum amount of cadmium that can be consumed by an individual weighs $50 \mathrm{~kg}$ is $0.35 \mathrm{mg} /$ week. If the Cd content exceeds MWI, it will cause $\mathrm{Cd}$ heavy metal poisoning. The value of MTI (Maximum Tolerable Intake) at $3 \mathrm{~cm}$ mussels size is $11.667 \mathrm{~kg}$ and $6 \mathrm{~cm}$ size is $10.601 \mathrm{~kg}$. The MTI value can be used as a reference for the weekly consumption of green mussels that are cultivated in the waters of $\mathrm{Pa}$ saran Island. If an individual weighing $50 \mathrm{~kg}$ consumes green mussels exceeding the MTI value, the heavy metal $\mathrm{Cd}$ will be toxic to humans.

ANOVA results using CRD Factorial showed that differences in mussels size and cultivation location differences did not affect $\mathrm{Cd}$ heavy metal concentration in the mussels body (Table 4). Quality standard value according to $\mathrm{SNI}$, limit of $\mathrm{Cd}$ heavy metal content in allowed mussels is $1.0 \mathrm{mg} / \mathrm{kg}$. Based on SNI, the Cd content in mussels cultivated in the waters of Pasaran Island at locations I, II and III is below the quality standard, therefore it is still suitable for consumption.

The discovery of Cd content in the mussels body cultivated at locations of $\mathrm{T} 1$ and $\mathrm{T} 2$ is assumed to originate from human activities. According to Vinodhini and Narayanan (2008), marine aquatic ecosystems are the main place for heavy metal contamination, among whi- 
ch comes from household waste channels. In addition, solar spills of fishing vessels also resulted in the presence of Cd in the waters (Azhar et al., 2012).

At the T3 location, the cage is directly facing industrial locations and ship traffic. One industry that is thought to affect the presence of $\mathrm{CD}$ in the waters is the coal mining industry activities. According to Shastri and Diwekar (2008) human activity (anthropogenic) contributing the most to the heavy metals existence in nature is burning fossil fuels (coal). The liquid waste generated from the coal washing process contains dangerous heavy metals, including cadmium which comes from the soil and rocks which are carried away during the coal exploitation process (Rukmana et al., 2013). Other activities that can lead to the occurrence of $\mathrm{Cd}$ are port activities (Galindo et al., 2010), one of the ports close to the location of green mussel cultivation, namely Panjang Port. Panjang Port has many activities such as loading and unloading of ships, export, import and container ship traffic.

Other factor affecting cadmium heavy metal content in the body of green musselsis the condition of the green mussel organ. Green mussels are able to produce Metalotionein which is a special protein that functions to bind heavy metal metals including $\mathrm{Cd}$ (Thirumoorthy et al., 2007). According to Klaassen et al. (1999) the role of Metalotionei as a protein involved in metabolism for the growth and development of organisms. According to Darmono (2006), cadmium heavy metals can be buried in tissues and bind to Metalotionein protein which is rather permanent and has a long half-life.
Green mussels have the ability to detoxify heavy metals. Detoxification itself is the ability to hold or concentrate metal elements (including toxic heavy metals) in the body by binding to metals in the metabolic circle without eliminating it, it is a temporary solution where the ability of confinement has its limitations (Bebianno and Langston, 1992). According to Sutamihardja (2006), based on heavy metal protein complexes, the Cd complex is not too toxic compared to $\mathrm{Cd}^{2+}$, but in the renal tubule cell complex Cd Metalotionein will release $\mathrm{Cd}^{2+}$ and produce toxic effects.

BCF calculations are needed to determine the body's ability to accumulate heavy metals. The higher the BCF value shows the higher the occurrence of bioconcentration in aquatic organisms body against heavy metals. The results of the calculation show that the average value of BFC in green mussels size $3 \mathrm{~cm}$ is $1.33 \mathrm{mg} / \mathrm{kg}$, while in green mussels size $6 \mathrm{~cm}$ is $1.47 \mathrm{mg} / \mathrm{kg}$ (Table 5). According to Hutagalung and Sutomo (1996), the size of BFC is influenced by the type of heavy metals, organisms, length of exposure, and environmental conditions of the waters. BFC can be categorized into 3 namely, (1) BFC values $>1000$ as high accumulative, (2) BFC 100-1000 value as moderate accumulative, and (3) $\mathrm{BFC}$ value $<100$ as accumulatively low (Amriarni et al., 2011).

Based on BFC calculation, the green mussels cultivated in the waters of $\mathrm{Pa}$ saran Island belongs to class 3. This finding shows that the ability of green mussels cultivated in the waters of Pasaran Island is still low in accumulating the presence of $\mathrm{Cd}$ in the waters. Although included in the low accumu- 
Tabel 5 BFC values of green mussels in the waters of Pasaran Island

\begin{tabular}{ccccc}
\hline \multirow{2}{*}{$\begin{array}{c}\text { Mussels size } \\
(\mathrm{cm})\end{array}$} & Location & \multicolumn{2}{c}{$\begin{array}{c}\text { Cd content } \\
(\mathrm{mg} / \mathrm{kg})\end{array}$} & \multirow{2}{*}{$\begin{array}{c}\text { BFC value } \\
(\mathrm{mg} / \mathrm{kg})\end{array}$} \\
\cline { 3 - 4 } 3 & & Mussel & Water & \\
\hline \multirow{3}{*}{3} & $\mathrm{~T} 1$ & 0.0333 & 0.022 & 1.53 \\
& $\mathrm{~T} 2$ & 0.03 & 0.022 & 1.36 \\
& $\mathrm{~T} 3$ & 0.0267 & 0.024 & 1.11 \\
6 & $\mathrm{~T} 1$ & 0.03 & 0.022 & 1.36 \\
& $\mathrm{~T} 2$ & 0.0333 & 0.022 & 1.51 \\
& $\mathrm{~T} 3$ & 0.0367 & 0.024 & 1.53 \\
\hline
\end{tabular}

lative category, the presence of $\mathrm{Cd}$ in green mussel meat needs to be heed because it has accumulative properties, therefore if consumed continuously and over a long period of time can have health effects, including damage on lung organs (Lampe et al., 2008), and lead to bone damage (Schutte et al., 2008).

\section{SIMPULAN}

Green mussels (Perna viridis) which are cultivated in the waters of Pasaran Island have low bioconcentration capabilities around $<100 \mathrm{mg} / \mathrm{l}$. The $\mathrm{Cd}$ content in seawater has exceeded the quality standard according to Minister of Environmental's Decree No.51 of 2014 (KEPMENLH RI No.51 of 2014) which is 0.022 and $0.024 \mathrm{mg} / \mathrm{l}$. The $\mathrm{Cd}$ content in green mussel meat is 0.030 $0.033 \mathrm{mg} / \mathrm{kg}$ which is still below the threshold based on SNI.

\section{Pustaka}

Almeida, J. A., Barreto, R. E., Novelli, E. L., Castro, F. J., and Moron, S. E. (2009). Oxidative stress biomarkers and aggressive behavior in fish exposed to aquatic cadmium contamination. Neotropical ichthyo$\log y, 7(1): 103-108$.
Amriarni, A., Hendrarto, B., and Hadiyarto, A. (2011). Bioakumulasi logam berat timbal (pb) dan seng (zn) pada kerang darah (anadara granosa 1.) dan kerang bakau (polymesoda bengalensis 1.) di perairan teluk kendari. Jurnal Ilmu Lingkungan, 9(2):45-50.

Azhar, H., Widowati, I., and Suprijanto, J. (2012). Studi kandungan logam berat $\mathrm{pb}, \mathrm{cu}, \mathrm{cd}$, cr pada kerang simping (amusium pleuronectes), air dan sedimen di perairan wedung, demak serta analisis maximum tolerable intake pada manusia. Journal of Marine Research, 1(2):35-44.

Bebianno, M. and Langston, W. (1992). Cadmium induction of metallothionein synthesis in mytilus galloprovincialis. Comparative Biochemistry and Physiology Part C: Comparative Pharmacology, 103(1):79-85.

Beesley, P. L., Ross, G. J., and Glasby, C. J. (2000). Polychaetes \& allies: the southern synthesis, volume 4 . CSIRO publishing.

Biagioli, M., Pifferi, S., Ragghianti, M., Bucci, S., Rizzuto, R., and Pinton, P. (2008). Endoplasmic reticulum stress and alteration in calcium homeostasis are involved in cadmium-induced apoptosis. Cell calcium, 43(2):184-195.

Darmono (2006). Lingkungan hidup dan pencemaran: hubungannya dengan toksikologi senyawa logam. Universitas Indonesia.

Dumalagan, H., Gonzales, A., and Hallare, A. (2010). Trace metal content in mussels, perna viridis 1., obtained from selected seafood markets in a metropolitan city. Bulletin of environmental contamination and toxicology, 84(4):492-496. 
Galindo, E. A. G., Barbosa, A. M., Velasco, M. R. M., Daessle, L. W., and Borbon, M. V. O. (2010). Distribution and enrichment of silver and cadmium in coastal sediments from bahia todos santos, baja california, mexico. Bulletin of environmental contamination and toxicology, 85(4):391-396.

Gandri, H., Mulyanto, and Yuni, K. (2017). Kandungan logam berat pb air laut, sedimen dan daging kerang hijau perna viridis. Jurnal Ilmu dan Teknologi Kelautan Tropis, 7(1):1-7. Isani, G., Andreani, G., Cocchioni, F., Fedeli, D., Carpene, E., and Falcioni, G. (2009). Cadmium accumulation and biochemical responses in sparus aurata following sub-lethal cd exposure. Ecotoxicology and environmental safety, 72(1):224-230.

Kamaruzzaman, B. Y., Zahir, M. M. S., John, B. A., Jalal, K. C. A., Shahbudin, S., Bawarni, S. M. A., and Goddard, J. S. (2011). Bioaccumulation of some metals by green mussel perna viridis (linnaeus 1758) from pekan, pahang, malaysia. International Journal of Biological Chemistry, 5(1):54-60.

Khaisar, O. (2006). Kandungan timah hitam (pb) dan kadmium (cd) dalam air, sedimen, dan bioakumulasi serta respon histopatologis organ ikan alu-alu (sphyraena barracuda) di perairan teluk jakarta. Skripsi. Fakultas Perikanan dan Ilmu Kelautan. Institut Pertanian Bogor. Bogor, 89.

Klaassen, C. D., Liu, J., and Choudhuri, S. (1999). Metallothionein: an intracellular protein to protect against cadmium toxicity. Annual review of pharmacology and toxicology, 39(1):267-294.
Kripa, V., Mohamed, K., Velayudhan, T., Joseph, M., Alloycious, P., and Jenni, B. (2009). Comparison of growth and gonad development of farmed green mussel perna viridis 1 . in three habitats. Journal of the Marine Biological Association of India, 51(2):199-204.

Lampe, B. J., Park, S. K., Robins, T., Mukherjee, B., Litonjua, A. A., Amarasiriwardena, C., Weisskopf, M., Sparrow, D., and Hu, H. (2008). Association between 24-hour urinary cadmium and pulmonary function among community-exposed men: the va normative aging study. Environmental health perspectives, 116(9):1226-1230.

Martin, P. and Pognonec, P. (2010). Erk and cell death: cadmium toxicity, sustained erk activation and cell death. The FEBS journal, 277(1):39-46.

Menke, A., Muntner, P., Silbergeld, E. K., Platz, E. A., and Guallar, E. (2008). Cadmium levels in urine and mortality among us adults. Environmental health perspectives, 117(2):190-196.

Mohiuddin, K., Ogawa, Y., Zakir, H., Otomo, K., and Shikazono, N. (2011). Heavy metals contamination in water and sediments of an urban river in a developing country. International journal of environmental science \& technology, 8(4):723736.

Nurdin, E. (2000). Potensi pengembanganan perikanan di situ pondok cina. Universitas Indonesia. Depok, Makara, pages 1-8.

Panjaitan, R., Yusuf, M., and Zainuri, M. (2014). Kajian pola sebaran padatan tersuspensi dan unsur logam berat di teluk ujung batu, jepara. 
Journal of Oceanography, 3(3):357365.

Pattikawa, J. A. and Ferdinandus, E. (2009). Growth of mangrove cockle (anandara antiquata) cultured in cages. Marine Research in Indonesia, 34(2):91-96.

Power, A. J., Walker, R. L., Payne, K., and Hurley, D. (2004). First occurrence of the nonindigenous green mussel, perna viridis (linnaeus, 1758) in coastal georgia, united states. Journal of Shellfish Research, 23(3):741-745.

Rukmana, T., Itnawati, S., and Anita (2013). Analisis logam mn, cd, sianida dan nitrit pada limbah cair tambang batubara pt tri bakti sarimas di pangkalan kuansing. Master's thesis, Fakultas Matematika dan Ilmu Pengetahuan Alam, Universitas Riau, Pekanbaru.

Schutte, R., Nawrot, T. S., Richart, T., Thijs, L., Vanderschueren, D., Kuznetsova, T., Van Hecke, E., Roels, H. A., and Staessen, J. A. (2008). Bone resorption and environmental exposure to cadmium in women: a population study. Environmental health perspectives, 116(6):777-783.

Sembel, L. (2011). Analisis logam berat $\mathrm{pb}$, cd dan cr berdasarkan tingkat salinitas di estuari sungai belau teluk lampung. Prosiding PERMAMA, pages 85-92.

Shastri, Y. and Diwekar, U. (2008). Optimal control of lake ph for mercury bioaccumulation control. ecological modelling, 216(1):1-17.

Simanjuntak, M. (2012). Kualitas air laut ditinjau dari aspek zat hara, oksigen terlarut dan ph di perairan banggai, sulawesi tengah. Jurnal Ilmu dan Teknologi Kelautan Tropis, 4(2):290-303.
Sreedevi, P. R., Uthayakumar, V., Jayakumar, R., Joseph, P., Kumar, D. S., and Ramasubramanian, V. (2014). Comparative valuation of on-bottom and off bottom mussel (perna viridis) culture as a small scale enterprise in chettuva estuary at kerala india. World Journal of Fish and Marine Science, 6:487-493.

Sutamihardja (2006). Toksikologi Lingkungan. Universitas Indonesia Press.

Thirumoorthy, N., Kumar, K. M., Sundar, A. S., Panayappan, L., and Chatterjee, M. (2007). Metallothionein: an overview. World journal of gastroenterology: WJG, 13(7):993.

Vinodhini, R. and Narayanan, M. (2008). Bioaccumulation of heavy metals in organs of fresh water fish cyprinus carpio (common carp). International Journal of Environmental Science \& Technology, 5(2):179182.

Whyte, A. L., Hook, G. R., Greening, G. E., Gibbs-Smith, E., and Gardner, J. P. (2009). Human dietary exposure to heavy metals via the consumption of greenshell mussels (perna canaliculus gmelin 1791) from the bay of islands, northern new zealand. Science of the Total Environment, 407(14):4348-4355.

Wiryawan, B., Marsden, B., Susanto, H. A., Mahi, A., Ahmad, M., and Poespitasari, H. (1999). Atlas sumberdaya wilayah pesisir lampung. Bandar Lampung: PEMDA TK I Lampung-CRMP Lampunng.

Yestyani (2010). Analisis kandungan logam berat pb, cd dan hg pada kerang darah anadara granosa di perairan bojonegara, kecamatan bojonegara, kabupaten serang. Master's thesis, Fakultas Perikanan dan 
Ilmu Kelautan, IPB, Bogor.

Yudha, I. (2007). Kajian pencemaran logam berat di wilayah pesisir kota bandar lampung. Universitas Lampung. Bandar Lampung.

Yulianto, H., Damai, A. A., Delis, P. C., and Elisdiana, Y. (2017). Spatial analysis to evaluate the suitability of seaweed farming site in lampung bay, indonesia. Turkish Journal of Fisheries and Aquatic Sciences, 17(6):1253-1261.

Yulianto, H., Hartoko, A., Anggoro, S., and Delis, P. C. (2016). Suitability analysis of pearl oyster farming in lampung bay, pesawaran, lampung province, indonesia. Aquaculture, Aquarium, Conservation \& Legislation-International Journal of the Bioflux Society (AACL Bioflux), $9(6)$. 
